Jurnal Qiraat

Fakulti Pengajian Peradaban Islam,

Kolej Universiti Islam Antarabangsa Selangor (KUIS)

Bandar Seri Putra, 43000 Kajang Selangor

2021, VOL 4, Bil 1, Halaman 1-13

\title{
Perancangan Pengajaran Dan Pembelajaran dan Penguasaan Hafazan Al-Quran Pelajar Sekolah Menengah Tahfiz
}

\section{Teaching and Learning (T\&L) Planning and Mastering Al-Quran Memorization of Tahfiz Secondary School Students}

\section{Mohamad Marzuqi Abdul Rahim¹, Wan Muhammad Hafizuddin Wan Abd Halim¹, Abd Hadi Borham $^{1}$, Ashraf Ismail'2, Tengku Nur Tasnim Tengku Riduan ${ }^{3}$}

${ }^{1}$ Fakulti Sains Kemanusiaan, Universiti Pendidikan Sultan Idris, Malaysia.

${ }^{2}$ Fakulti Pengajian Islam, Universiti Kebangsaan, Malaysia.

${ }^{3}$ SMK Seri Perpatih Gemas Negeri Sembilan, Malaysia.

${ }^{*}$ Corresponding Author: Prof Madya Dr. Mohamad Marzuqi Abdul Rahim, Jabatan Pengajian Islam, Fakulti Sains Kemanusiaan, 35900 Tanjong Malim, marzuqi@fsk.upsi.edu.my

\section{ABSTRACT}

Teaching and learning (T\&L) planning is a very important aspect of education. All areas of teaching and learning including tahfiz al-Quran can be achieved through appropriate and accurate planning. Effective teaching and learning planning will have an impact on learning. Therefore, this study was conducted to identify the implementation of tahfiz teaching and learning planning as well as the level of mastering memorization of the Quran. This study is a quantitative study. A total of 335 respondents were selected at simple random from several private and government tahfiz institutions. Study data were collected using a questionnaire. and subsequently analyzed descriptively using frequency, percentage, mean, standard deviation values. While inferential analysis uses Pearson Correlation Coefficient Test. The results of the study found that teaching and learning planning as a whole, was at a moderately high level (mean 3.98, sd =0.43), Similarly, the findings also showed that students' memorization mastery was at a moderately high level of interpretation (mean 3.83, sd =0.39). Meanwhile, the overall Pearson correlation findings showed that there was a very high significant relationship between the teaching management and learning of tahfiz teachers in the memorization class with students' memorization mastery with a value $(r=0.843, p<0.01)$. Overall, the findings of the study on the mastery of memorization that is at a medium to high level need to be further improved, especially the mastery of consistent takrar, tahriri al-Quran, tasmi ' peer, fiqh al-ayat and mastery of verses mutasyabihat lafzi. T\&L tahfiz planning can be formulated as having a direct relationship with students' memorization mastery. The implications of the study show that the teaching and learning planning of tahfiz is very important in determining the level of students' memorization mastery. Therefore, the planning of teaching and learning tahfiz should be arranged more systematically on the aspects of goals, time, T\&L activities, T\&L materials and recording so that it gives maximum impact on students' memorization.

Keywords

Planning, Teaching and Learning (T\&L), Tahfiz, mastering memorization, tahfiz school 


\section{ABSTRAK}

Perancangan pengajaran dan pembelajaran merupakan satu aspek yang sangat mustahak dalam pendidikan. Semua bidang pengajaran dan pembelajaran termasuk Tahfiz al-Quran dapat dijayakan melalui perancangan yang sesuai dan tepat. Perancangan pengajaran dan pembelajaran yang berkesan akan memberi impak kepada penguasaan pembelajaran. Oleh itu, kajian ini dijalankan bagi mengenal pasti pelaksanaan perancangan pengajaran dan pembelajaran tahfiz serta tahap penguasaan peserta kajian terhadap hafazan al-Quran. Kajian ini merupakan kajian kuantitatif. Seramai 335 orang responden dipilih secara rawak mudah daripada beberapa institusi tahfiz swasta dan kerajaan. Data kajian telah dikumpul menggunakan soal selidik. dan seterusnya dianalisis secara deskriptif menggunakan nilai kekerapan, peratus, min, sisihan piawai. Manakala analisis inferensi pula menggunakan Ujian Pekali Korelasi Pearson. Hasil kajian mendapati perancangan pengajaran dan pembelajaran secara keseluruhannya, berada pada tahap sederhana tinggi (min 3.98, sp=0.43), Begitu juga dapatan kajian turut menunjukkan penguasaan hafazan pelajar berada di tahap interpretasi sederhana tinggi (min 3.83, sp=0.39). Sementara itu dapatan korelasi pearson secara keseluruhan menunjukkan terdapat hubungan signifikan yang sangat tinggi di antara pengurusan pengajaran dan pembelajaran guru tahfiz di dalam kelas hafazan dengan penguasaan hafazan pelajar dengan nilai $(r=0.843, p<0.01)$. Secara keseluruhan dapatan kajian terhadap penguasaan hafazan yang berada pada tahap sederhana tinggi perlu ditingkatkan lagi khususnya menguasai takrar yang konsisten, tahriri al-Quran, rakan tasmi', fiqh al-ayat dan penguasaan ayat-ayat mutasyabihat lafzi. Perancangan PdP tahfiz pula boleh dirumuskan sebagai mempunyai kaitan langsung dengan penguasaan hafazan pelajar. Implikasi kajian menunjukkan perancangan pengajaran dan pembelajaran tahfiz sangat penting dalam menentukan tahap penguasaan hafazan pelajar. Oleh yang demikian, perancangan pengajaran dan pembelajaran tahfiz harus disusun dengan lebih sistematik terhadap aspek matlamat, masa, aktiviti PdP, bahan PdP dan perekodan agar ia memberikan impak yang maksimum kepada penguasaan hafazan pelajar.

\section{Kata Kunci}

Perancangan, Pengajaran dan pPmbelajaran (PdP), tahfiz, penguasaan hafazan, sekolah tahfiz

\subsection{PENGENALAN}

Kejayaan sebuah negara banyak bergantung pada perancangan pendidikan. Di sekolah guru adalah perancang kepada pengajaran dan pembelajaran untuk kemenjadian pelajar mendepani cabaran masa hadapan (Zulkifly, 2020). Kemenjadian pelajar ini dirancang melalui penetapan dan penyusunan objektif PdP secara bertahap dan berterusan. Menurut Norashikin et.al (2015) perancangan pengajaran dan pembelajaran bermaksud pemahaman guru tentang apa yang harus diajar dan bagaimana pengajaran perlu dilakukan dengan mengambil kira kesesuaian pelajar dan keperluan isi kandungan bidang tersebut.

Institusi tahfiz terus berkembang pesat kerana permintaan tinggi daripada masyarakat terhadap pendidikan yang berteraskan kepada tahfiz al-Quran. Pelbagai reka bentuk kurikulum ditawarkan kepada ibu bapa yang berhasrat memasukkan anak-anak mereka ke sekolah aliran tahfiz antaranya tahfiz turath (tulen), tahfiz dini (pengajian Islam), tahfiz sains dan tahfiz kemahiran atau vokasional. Walau bagaimanapun matlamat utama semua jenis kurikulum tahfiz al-Quran ialah untuk pelajar mengingati al-Quran tanpa mudah lupa di samping ilmu pengetahuan dan kemahiran lain (Zulkifli et.al, 2018). Ini menunjukkan penguasaan hafazan al-Quran pelajar adalah menjadi indikator utama kejayaan sesebuah sekolah tahfiz. Hal yang demikian boleh dicapai melalui perancangan pengajaran dan pembelajaran (PdP) guru tahfiz secara sistematik dan berterusan. Impilkasinya akan menambah keyakinan masyarakat terhadap prospek pendidikan tahfiz alQuran. 
Rohani et.al (2017) menjelaskan komponen penting perancangan PdP oleh guru merangkumi aspek seperti penetapan objektif atau hasil pembelajaran, penyediaan sumber dan bahan PdP, pemilihan kaedah dan strategi pengajaran serta penilaian merupakan. Oleh itu merancang PdP adalah sebahagian dari tugas guru. Justeru perancangan PdP boleh dikategorikan kepada tiga aspek utama; iaitu perancangan pendokumentasian, perancangan komitmen dan perancangan pelaksanaan kepada pengajaran. (Mohd Syaubari \& Ahmad Yunus, 2018).

Perancangan pendokumentasian melibatkan kemahiran guru tahfiz dalam menguruskan rekod berkaitan dengan PdP tahfiz. Sebelum proses PdP guru tahfiz seharusnya merancang untuk mendapatkan rekod berkaitan dengan profil pelajar. Maklumat lengkap profil pelajar dapat membantu keberkesanan PdP (Muhammad Firdaus, 2018). Sementara itu bahan-bahan seperti kurikulum atau sukatan hafazan, rancangan mengajar harian dan sumber-sumber bahan pengajaran akan disediakan terlebih dahulu sebelum mengajar. Semasa berlangsungnya proses tasmi rekod kehadiran, rekod pencapaian hafazan, rekod tahriri pelajar akan disemak dan dinilai (Wan Ahmad Zakry, Firdaus Khairi \& Azman, 2021). Guru-guru tahfiz di dalam kajian Mohamad Marzuqi et.al (2018) didapati amat patuh dan berkemahiran dalam menyimpan rekod-rekod berkaitan hafazan pelajar.

Perancangan dari aspek komitmen pula memerlukan guru menguruskan masa dengan baik sebelum, semasa dan selepas PdP hafazan dilaksanakan. Walau bagaimanapun terdapat juga isu merancang masa pengajaran dan pembelajaran dengan baik dan berkesan. Mardhiah (2016) melaporkan guru tahfiz tidak dapat mempelbagaikan aktiviti PdP hafazan seperti tahriri al-Quran kerana menganggap masa yang diperuntukkan adalah terhad. Hal ini menunjukkan kelemahan pengurusan dari sudut perancangan masa guru yang akan mengakibatkan komitmen terhadap pengajaran dan pembelajaran terganggu. Selain itu menurut Raedah (2013) terdapat segelintir guru mengambil kesempatan lewat masuk ke kelas dan melengah-lengahkan pengajaran dan pembelajaran kerana kurangnya mekanisme atau kawalan keluar masuk guru.

Sementara itu perancangan pelaksanaan PdP pula melibatkan penyusunan aktiviti pengajaran, membuat penilaian serta pengukuhan PdP. Semua perancangan ini didokumentasikan bagi memudahkan semakan dan pemantauan pencapaian perancangan (Siti Nurjanah, Siti Aisyah, \& Jimaain Safar, 2020). Perancangan pelaksanaan ini perlu dibuat secara berterusan iaitu sebelum, semasa dan selepas pengajaran. (Rohani et.al, 2017) setelah itu refleksi kepada perancangan ini akan melihat kepada pencapaian objektif atau hasil pembelajaran yang diharapkan Hal ini telah diingatkan oleh Allah SWT supaya kita merancang kaedah dan strategi dalam melaksanakan sesuatu yang penting (Al-Quran, Surah al-Anfal, 8: 60).

Walaupun merancang PdP merupakan tugas penting guru, namun begitu terdapat kajian yang menunjukkan guru tahfiz tidak merancang dengan baik seperti tidak meletakkan matlamat dan sasaran yang jelas terhadap hafazan pelajar mereka. Akibatnya ramai pelajar tidak mencapai sasaran hafazan yang diharapkan. Kajian Wan Ahmad Zakry et.al (2021) menunjukkan 46.1\% daripada 2,438 pelajar tidak berjaya mencapai sasaran hafazan sekurang-kurangnya 20 juzuk al-Quran bagi tempoh tahun 2010 hingga 2015 di Sekolah Imtiaz Terengganu.

Dari aspek perancangan kaedah dan strategi PdP pula, kajian menunjukkan sebahagian guru tahfiz masih mengekalkan aktiviti pengajaran secara tradisional dan sukar untuk mempelbagaikan kaedah dan teknik dan bahan pengajaran mereka. (Mohamad Marzuqi, 2016). Kajian Misnan Jemali dan Ahmad Sadadi (2003) mendapati kaedah, strategi, teknik dan motivasi kurang diaplikasikan oleh guru di dalam kelas Sementara itu Mohd Jamalil et.al (2017) turut menyokong bahawa perkara yang selalu dilaksanakan dan menjadi amalan dalam tahfiz seperti talaqqi, ujian mingguan, penulisan ayat, pemahaman ayat kurang diaplikasikan 
oleh guru dalam pembelajaran tahfiz. Hal yang demikian menunjukkan kelemahan guru dalam merancang kaedah dan strategi PdP yang berkesan.

Perancangan PdP diharapkan menghasilkan kemenjadian pelajar. Salah satu aspek kemenjadian pelajar ialah penguasaan mereka terhadap isi kandungan yang dipelajari. Penguasaan bermaksud daya dan kemampuan terhadap sesuatu. Oleh itu penguasaan hafazan bermaksud daya dan kemampuan pelajar menghafaz al-Quran tanpa mudah lupa (Muhaidi \& Siti Salwa, 2018). Menurut Abdul Hafiz et.al (2018) aspek penguasaan hafazan yang sering menjadi isu pengkaji ialah pencapaian dan kualiti hafazan, penulisan ayat-ayat hafazan, penguasaan ilmu tajwid dan kekeliruan terhadap ayat-ayat mutasyabihat lafzi iaitu ayatayat yang mempunyai lafaz yang hampir sama (Mahmud Lutfi \& Ahmad Shahir (2015). Dalam kajian ini penguasaan merangkumi empat aspek yang tersebut dengan penambahan aspek memahami makna ayat yang dihafaz. Aspek kelima ini telah dinyatakan oleh al-Qabisi (1968) yang berpandangan penguasaan tahfiz bukan hanya diukur dari sudut kelancaran malah turut merangkumi aspek kefahaman dan keupayaan membariskan al-Quran.

Beberapa kajian seperti kajian Azmil (2010) menunjukkan pencapaian pelajar masih belum mencapai objektif pendidikan tahfiz yang telah digariskan iaitu menghafaz al-Quran dengan lancar. Tambahan pula menurut Khairul Anuar (2016) seseorang yang telah menamatkan hafazan 30 juzuk al-Quran semasa persekolahan belum terjamin dapat mengekalkan ingatan hafazan al-Quran tersebut sepanjang hayat. Begitu juga dapatan kajian Asyraf (2018) menunjukkan pencapaian pengekalan terhadap hafazan pelajar tahfiz berada pada tahap yang lemah dan dapat dikesan melalui dapatan ujian syafawi.

Pelajar-pelajar tahfiz juga didapati tidak dapat mencapai pemahaman maksud ayat yang dihafaz. Kajian Mohamad Marzuqi et.al (2018) mendapati sebanyak 66.3\% pelajar berada pada skor yang rendah iaitu antara skor 0-5 dalam konteks menterjemah ayat al-Quran. Apatah lagi, kemahiran mengeluarkan ayatayat tertentu berdasarkan hukum atau maudhu' juga didapati masih lemah. Oleh yang demikian kajian ini dijalankan bagi menjawab persoalan kajian yang digariskan daripada isu-isu berkaitan perancangan pengajaran dan penguasaan hafazan pelajar tahfiz.

\subsection{OBJEKTIF KAJIAN}

Kajian ini dijalankan bertujuan untuk mencapai objektif berikut:

1- Mengenal pasti perancangan guru daripada aspek matlamat, masa, kaedah PdP, bahan PdP dan perekodan hafazan

2- Mengela pasti tahap penguasaan responden terhdap hafazan al-Quran.

3- Menilai hubungan perancangan guru dengan penguasaan pelajar terhadap hafazan al-Quran menurut persepsi responden.

\subsection{METODOLOGI KAJIAN}

Kajian ini dilakukan menggunakan pendekatan kuantitatif melalui kajian tinjauan yang berbentuk deskriptif dan inferensi. Soal selidik yang digunakan telah diubah suai daripada kajian lepas yang mengandungi dua konstruk utama iaitu konstruk perancangan PdP dan konstruk penguasaan hafazan Al-Quran. Skala likert lima mata digunakan dalam soal selidik ini bagi mengikut maklum balas daripada responden terhadap pelaksanaan kajian ini.

Jumlah populasi kajian yang telah dikenal pasti bagi sekolah menengah tahfiz yang dikaji ialah 685 orang. Sekolah ini dipilih berasaskan kepada demografi yang berbeza iaitu kategori sekolah tahfiz kerajaan dan swasta. Ke semua sekolah tahfiz ini juga merupakan sekolah yang mempunyai populasi terbanyak pelajar 
yang mengikuti aliran tahfiz di Negeri Sembilan. Sampel kajian dipilih secara rawak mudah iaitu sejumlah 335 orang pelajar daripada keseluruhan populasi. Pemilihan sampel ini dilakukan kerana mewakili semua ciri yang sama dan mencukupi untuk saiz sampel yang diperlukan menurut penentuan sampel kajian Krejcie \& Morgan (1970). Berdasarkan jadual Krejcie \& Morgan, bilangan sampel yang diperlukan adalah lebih kurang seramai 248 orang jika jumlah populasi kajian bersamaan 700 orang. Oleh itu jumlah sampel 335 dipilih oleh pengkaji adalah melebihi daripada jumlah yang dicadangkan oleh oleh Krejcie \& Morgan. Taburan sampel kajian adalah seperti yang ditunjukkan dalam jadual 1.

Jadual 1: Taburan Sampel Kajian Mengikut Kategori Sekolah, Jantina dan Tingkatan

\begin{tabular}{lcccc}
\hline \multirow{2}{*}{ Kategori sekolah } & \multicolumn{2}{c}{ Jantina } & \multicolumn{2}{c}{ Tingkatan } \\
\cline { 2 - 5 } & lelaki & Perempuan & Dua & Empat \\
\hline SM Tahfiz Kerajaan & 98 & 102 & 105 & 95 \\
SM Tahfiz Swasta & 68 & 67 & 75 & 60 \\
\hline Jumlah & 166 & 169 & 180 & 155 \\
\hline
\end{tabular}

Bagi menentukan kesahan dalaman, soal selidik yang dibina telah dirujuk kepada beberapa orang yang mempunyai kepakaran dan pengalaman luas dalam bidang masing-masing yang terdiri daripada kepakaran dalam bidang tahfiz dan penyelidikan. Sementara itu kebolehpercayaan instrumen yang digunakan dalam kajian ini berada pada tahap yang tinggi iaitu nilai alpha Cronbach 0.934. Menurut Chua (2003) kebanyakan pengkaji menganggap nilai alpha yang melebihi 0.80 mempunyai kebolehpercayaan yang tinggi dan boleh diterima sebagai instrumen kajian.

\subsection{DAPATAN KAJAN}

\subsection{Perancangan PdP Tahfiz}

Dapatan kajian pada bahagian ini adalah mengukur tahap perancangan PdP di sekolah-sekolah tahfiz swasta dan kerajaan di Negeri Sembilan. Sejumlah sepuluh item dikemukakan kepada responden bagi mendapatkan maklum balas mereka berkaitan konstruk perancangan PdP. Maklum balas responden adalah dalam bentuk skala likert lima mata iaitu dari skala 1 untuk sangat tidak setuju dan seterusnya tidak setuju, kurang setuju, setuju dan sangat setuju pada skala 5 .

Jadual 1 menunjukkan peratus, kekerapan, min dan sisihan piawai. Dapatan kajian pada jadual 1 berkaitan perancangan PdP Tahfiz menunjukkan lima item berada pada tahap tinggi dengan julat min diantara 4.12 hingga 4.62. Item yang mempunyai nilai interpretasi min paling tinggi ialah item 7 iaitu guru merancang target untuk pencapaian hafazan pelajar $(\min =4.62, \mathrm{sp}=0.53)$.

Jadual 2. Analisis Kekerapan, Peratus, Min dan Sisihan Piawai bagi Perancangan PdP Tahfiz

\begin{tabular}{|c|c|c|c|c|c|c|c|c|c|}
\hline \multirow{2}{*}{ Bil } & \multirow{2}{*}{ Item } & \multicolumn{5}{|c|}{ Kekerapan \& Peratus $(n=355)$} & \multirow[b]{2}{*}{ Min } & \multirow[b]{2}{*}{$\mathbf{S P}$} & \multirow[b]{2}{*}{ Interpretasi } \\
\hline & & STS & TS & KS & $\mathbf{S}$ & SS & & & \\
\hline 1 & $\begin{array}{l}\text { Guru saya merancang } \\
\text { untuk masuk lebih awal }\end{array}$ & $\begin{array}{c}18 \\
(5.4)\end{array}$ & $\begin{array}{c}116 \\
(34.5)\end{array}$ & $\begin{array}{c}83 \\
(24.7)\end{array}$ & $\begin{array}{c}78 \\
(23.2)\end{array}$ & $\begin{array}{c}40 \\
(11.9)\end{array}$ & 3.02 & 1.12 & $\begin{array}{l}\text { Sederhana } \\
\text { Tinggi }\end{array}$ \\
\hline
\end{tabular}


Guru saya menepati waktu semasa memulakan pengajaran tasmik.

$\begin{array}{llll}0 & 39 & 91 & 98\end{array}$

(0)

(11.6)

(27.1)

(29.2)

107

(31.8)

3.8

1.01

3

Guru saya terlebih dahulu memastikan pelajar bersedia setiap kali waktu pengajaran.

4

Guru menetapkan matlamat dan objektif pembelajaran dengan jelas.

5 Guru menanda buku rekod prestasi hafazan harian pelajar setiap kali masuk ke kelas.

$6 \quad$ Guru saya mengemas kini kehadiran pelajar semasa memulakan pengajaran.

Guru saya merancang target untuk pencapaian hafazan pelajar.

Guru menerangkan tugas yang perlu dilaksanakan pelajar sebelum kelas tasmik bermula.
$\begin{array}{cc}0 & 36 \\ (0) & (10.7)\end{array}$
107
139
$(41.4)$
53
$(15.8)$
3.62
0.87
Sederhana Tinggi

$\begin{array}{cccccccc}0 & 14 & 55 & 143 & 123 & 4.12 & 0.83 & \text { Tinggi } \\ (0) & (4.2) & (16.4) & (42.7) & (36.7) & & & \end{array}$

$\begin{array}{cccccccc}4 & 16 & 33 & 128 & 154 & 4.23 & 0.89 & \text { Tinggi } \\ (1.2) & (4.8) & (9.9) & (38.2) & (46.0) & & & \end{array}$

$\begin{array}{cccccccc}8 & 0 & 27 & 106 & 194 & 4.43 & 0.83 & \text { Tinggi } \\ (2.4) & (0) & (8.1) & (31.6) & (57.9) & & & \\ & & & & & & & \\ 0 & 0 & 8 & 111 & 216 & 4.62 & 0.53 & \text { Tinggi } \\ (0) & (0) & (2.4) & (33.1) & (64.5) & & & \\ & & & & & & & \\ 0 & 6 & 44 & 158 & 127 & 4.21 & 0.73 & \text { Tinggi } \\ (0) & (1.8) & (13.1) & (47.2) & (37.9) & & & \end{array}$

Guru saya merancang aktiviti pengajaran yang $0 \quad 14$

110

126

85
$(25.4)$

3.84

0.85

Sederhana

Guru saya merancang bahan pengajaran yang secukupnya sebelum bermula.
(0)

(4.2) sesuai dengan minat pelajar. waktu pengajaran

Tinggi

\begin{tabular}{cccccccc}
0 & 14 & 70 & 168 & 83 & 3.96 & 0.79 & Sederhana \\
$(0)$ & $(4.2)$ & $(20.9)$ & $(50.1)$ & $(24.8)$ & & & Tinggi \\
& & & & & & & \\
& & & & & & & \\
\hline
\end{tabular}

Keseluruhan
3.98

$0.43 \quad \begin{gathered}\text { Sederhana } \\ \text { inggi }\end{gathered}$

Dari segi kekerapan dan peratus item 7 menunjukkan majoriti pelajar (327 orang, 97.6\%) menyatakan bahawa guru merancang target untuk pencapaian pelajar. Hanya 8 orang pelajar $(2.5 \%)$ sahaja yang tidak bersetuju dengan item ini. Seterusnya item "Guru menerangkan tugas yang perlu dilaksanakan pelajar sebelum kelas tasmik bermula" memperoleh skor min kedua tertinggi ( $\min =4.21, \mathrm{sp}=0.73$ ). Begitu juga item "Guru saya mengemas kini kehadiran pelajar semasa memulakan pengajaran" memperoleh skor $(\min =4.43, \mathrm{sp}=0.83)$. Selain itu, bagi item "Guru menanda buku rekod prestasi hafazan harian pelajar setiap 
kali masuk ke kelas" memperoleh skor ( $\min =4.23, \mathrm{sp}=0.89$ ). Bagi item "Guru menetapkan matlamat dan objektif pembelajaran dengan jelas" pula memperoleh skor $(\min =4.12, \mathrm{sp}=0.83)$. Kesemua item yang berada di tahap tinggi ini mewakili aspek matlamat dan perekodan.

Sementara itu, bagi item "Guru saya merancang bahan pengajaran yang secukupnya sebelum waktu pengajaran bermula" skor min yang diperoleh adalah sebanyak min=3.96, $\mathrm{sp}=0.79$ ). Kemudian, bagi item "Guru saya merancang aktiviti pengajaran yang sesuai dengan minat pelajar" skor min yang diperoleh adalah sebanyak $(\min =3.84, \mathrm{sp}=0.85$ ). Selanjutnya, bagi item "Guru saya menepati waktu semasa memulakan pengajaran tasmik" berada pada skor $\min (\min =3.81, \mathrm{sp}=1.01)$. Kemudian daripada itu, bagi item "Guru saya terlebih dahulu memastikan pelajar bersedia setiap kali waktu pengajaran" min yang diperoleh adalah sebanyak $(\min =3.62, \mathrm{sp}=0.87)$.

Item yang mendapat nilai min terendah ialah item "Guru saya merancang untuk masuk lebih awal ke dalam kelas" ( $\min =3.02, \mathrm{sp}=1.12$ ). Item ini menunjukkan peratusan yang tinggi pada nilai tidak bersetuju iaitu (18 orang 5.4\%) sangat tidak bersetuju, (116 orang 34.5\%) tidak bersetuju, ( 83 orang $24.7 \%$ ) kurang bersetuju. Hanya sebilangan kecil sahaja bersetuju guru merancang untuk masuk lebih awal ke dalam kelas iaitu (118 orang 35.1\%). Hal ini menunjukkan pengurusan masa guru dalam menepati jadual kelas hafazan adalah membimbangkan.

Dapatan secara keseluruhan menunjukkan konstruk perancangan PdP Tahfiz berada pada tahap sederhana tinggi ( $\min =3.98 \mathrm{sp}=0.43$ ). Hal ini disebabkan beberapa item seperti "Guru saya merancang untuk masuk lebih awal ke dalam kelas", "Guru saya merancang bahan pengajaran yang secukupnya sebelum waktu pengajaran bermula", "Guru saya menepati waktu semasa memulakan pengajaran tasmik" dan "Guru saya terlebih dahulu memastikan pelajar bersedia setiap kali waktu pengajaran" mendapat nilai min yang sederhana tinggi.

\subsection{Penguasaan Hafazan Al-Quran Pelajar}

Kajian turut melihat tahap penguasaan hafazan al-Quran oleh pelajar. Sebanyak 11 item dikemukakan di dalam konstruk ini. Jadual 2 menunjukkan peratus, kekerapan, min dan sisihan piawai tahap penguasaan hafazan al-Quran dari persepsi responden.

Jadual 3. Analisis Kekerapan, Peratus, Min dan Sisihan Piawai bagi Penguasaan Hafazan Al-Quran Pelajar

\begin{tabular}{|c|c|c|c|c|c|c|c|c|c|}
\hline \multirow{2}{*}{ Bil } & \multirow{2}{*}{ Item } & \multicolumn{5}{|c|}{ Kekerapan \& Peratus $(n=335)$} & \multirow{2}{*}{ Min } & \multirow{2}{*}{$\mathbf{S P}$} & \multirow{2}{*}{ Interpretasi } \\
\hline & & STS & TS & KS & $\mathbf{S}$ & SS & & & \\
\hline 1 & $\begin{array}{l}\text { Saya mampu murajaah } \\
\text { ayat yang telah dihafaz } \\
\text { pada setiap hari. }\end{array}$ & $\begin{array}{c}12 \\
(3.6)\end{array}$ & $\begin{array}{c}7 \\
(2.1)\end{array}$ & $\begin{array}{c}31 \\
(9.3)\end{array}$ & $\begin{array}{c}163 \\
(48.7)\end{array}$ & $\begin{array}{c}122 \\
(36.4)\end{array}$ & 4.12 & 0.92 & Tinggi \\
\hline 2 & $\begin{array}{l}\text { Saya mampu } \\
\text { memperbetulkan bacaan } \\
\text { rakan tanpa melihat } \\
\text { mushaf. }\end{array}$ & $\begin{array}{c}0 \\
(0)\end{array}$ & $\begin{array}{c}4 \\
(1.2)\end{array}$ & $\begin{array}{c}130 \\
(38.8)\end{array}$ & $\begin{array}{c}91 \\
(27.2)\end{array}$ & $\begin{array}{c}110 \\
(32.8)\end{array}$ & 3.92 & 0.87 & $\begin{array}{l}\text { Sederhana } \\
\text { Tinggi }\end{array}$ \\
\hline 3 & $\begin{array}{l}\text { Saya mampu menulis ayat } \\
\text { yang telah dihafaz tanpa } \\
\text { melihat mushaf. }\end{array}$ & $\begin{array}{c}0 \\
(0)\end{array}$ & $\begin{array}{c}2 \\
(0.6)\end{array}$ & $\begin{array}{c}247 \\
(73.7)\end{array}$ & $\begin{array}{c}44 \\
(13.1)\end{array}$ & $\begin{array}{c}42 \\
(12.5)\end{array}$ & 3.38 & 0.70 & $\begin{array}{l}\text { Sederhana } \\
\text { Tinggi }\end{array}$ \\
\hline 4 & $\begin{array}{l}\text { Saya mudah mengingat } \\
\text { ayat yang baru dihafaz } \\
\text { semasa tasmik. }\end{array}$ & $\begin{array}{c}0 \\
(0)\end{array}$ & $\begin{array}{c}14 \\
(4.2)\end{array}$ & $\begin{array}{c}55 \\
(16.4)\end{array}$ & $\begin{array}{c}143 \\
(42.7)\end{array}$ & $\begin{array}{c}123 \\
(36.7)\end{array}$ & 4.12 & 0.82 & Tinggi \\
\hline
\end{tabular}




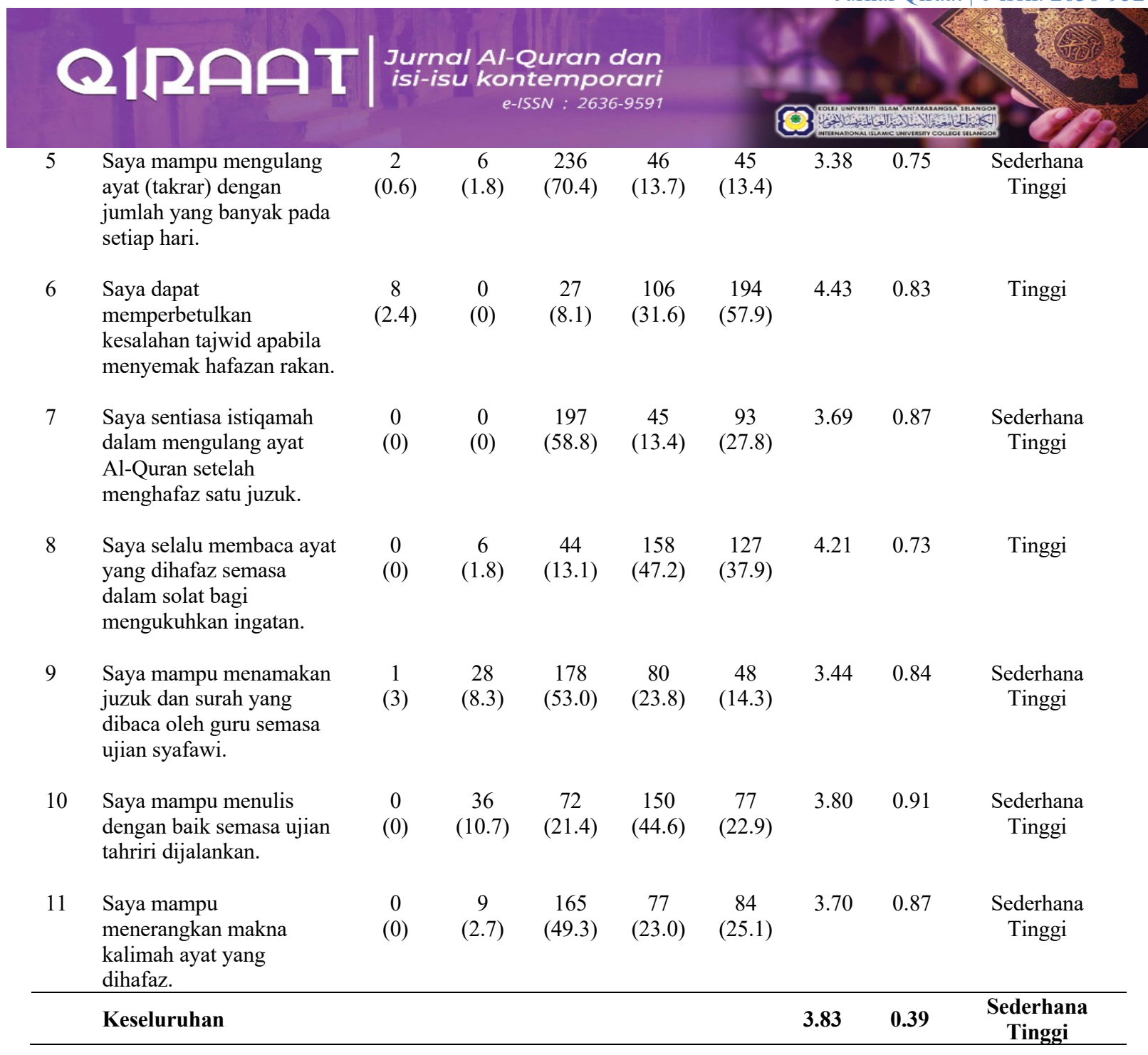

Hasil Analisis di dalam jadual 2 menunjukkan empat item berada pada tahap yang tinggi iaitu dengan julat min di antara 4.12 hingga 4.43. Sementara tujuh lagi item berada pada tahap sederhana tinggi iaitu dengan julat min diantara 3.38 hingga 3.92. Item yang mempunyai nilai interpretasi min paling tinggi ialah item dapat memperbetulkan kesalahan tajwid apabila menyemak hafazan rakan $(\min =4.43, \mathrm{sp}=0.83)$

Dari segi kekerapan dan peratus item yang mendapat nilai min paling tinggi ini menunjukkan majoriti pelajar (194 orang, 57.9\%) sangat bersetuju, (106 orang 31.6\%) bersetuju dan (27 orang 8.1\%) kurang bersetuju. Hanya (8 orang $2.4 \%$ ) sahaja yang menyatakan sangat tidak bersetuju. Seterusnya item "Saya selalu membaca ayat yang dihafaz semasa dalam solat bagi mengukuhkan ingatan" memperoleh skor min sebanyak ( $\min =4.21, \mathrm{sp}=0.73$ ). Begitu juga dengan item "Saya mampu murajaah ayat yang telah dihafaz pada setiap hari" mendapat skor min sebanyak $(\min =4.12, \mathrm{sp}=0.92)$ dan item "saya mudah mengingat ayat yang baru dihafaz semasa tasmik" juga mendapat skor min sebanyak (min 4.12, $\mathrm{sp}=0.82$ )

Sementara itu item yang mendapat nilai min sederhana tinggi ialah "Saya mudah mengingat ayat yang baru dihafaz semasa tasmik" mendapat skor min sebanyak $(\min =4.12, \mathrm{sp}=0.82)$, diikuti item "Saya mampu mengulang ayat (takrar) dengan jumlah yang banyak pada setiap hari" mendapat skor min sebanyak $(\min =3.38, \mathrm{sp}=0.75)$ dan item "Saya mampu menulis dengan baik semasa ujian tahriri dijalankan." 
$(\min =3.80, \mathrm{sp}=0.91)$. Seterusnya item "Saya mampu memperbetulkan bacaan rakan tanpa melihat mushaf" pula memperoleh skor min sebanyak $(\min =3.92, \mathrm{sp}=0.87$ diikuti item "Saya mampu menerangkan makna kalimah ayat yang dihafaz" memperoleh skor min sebanyak (min=3.70, $\mathrm{sp}=0.87$ ). Hal ini menunjukkan aspek-aspek penting dalam penguasaan hafazan seperti takrar, tahriri al-Quran, tasmi' rakan dan fiqh alayat masih belum dikuasai sepenuhnya oleh pelajar.

Item yang mendapat nilai min terendah ialah item "Saya mampu menamakan juzuk dan surah yang dibaca oleh guru semasa ujian syafawi". Item ini menunjukkan peratusan yang tinggi pada nilai kurang setuju iaitu (178 orang 53.0\%) di mana pelajar tidak pasti mampu menamakan juzuk dan surah yang dibaca oleh guru semasa ujian syafawi”. Hal ini menunjukkan kesukaran pelajar untuk mengingat secara tepat nama dan juzuk daripada ayat yang dihafaz berkemungkinan kerana kesamaran ayat pada beberapa surah. Dapatan menunjukkan secara keseluruhan penguasaan pelajar tahfiz dalam hafazan al-Quran berada pada tahap sederhana tinggi $(\min =3.83 \mathrm{sp}=039)$. Ini adalah disebabkan kerana hampir keseluruhan item berada pada tahap sederhana tinggi dan hanya empat item sahaja berada pada tahap tinggi.

\subsection{Hubungan Perancangan PdP Guru dengan Penguasaan Hafazan Pelajar}

Untuk mengkaji hubungan di antara pemboleh ubah perancangan PdP tahfiz dan penguasaan hafazan, ujian korelasi pearson telah dijalankan ke atas data yang diperolehi. Berdasarkan jadual 3, dapatan kajian menunjukkan terdapat korelasi antara perancangan dengan penguasaan hafazan pelajar. Ini menunjukkan terdapat hubungan positif yang signifikan pada tahap yang sangat kukuh di antara perancangan PdP Guru Tahfiz dengan tahap penguasaan hafazan al-Quran di mana $(r=0.843, p<0.01)$

Jadual 4. Korelasi Antara Pengurusan Guru Tahfiz Di Dalam Kelas Hafazan Dengan Tahap Penguasaan Hafazan Pelajar.

\begin{tabular}{lcc}
\hline & $\mathrm{r}$ & Sig.P \\
\hline Perancangan PdP Guru Tahfiz * Penguasaan hafazan & $0.843^{* *}$ & 0.000 \\
$\begin{array}{l}* * \text { Korelasi adalah signifikan pada aras } \mathrm{p}<0.01 \\
\mathrm{n}=335\end{array}$ & & \\
\end{tabular}

\subsection{PERBINCANGAN}

Secara keseluruhannya analisis dapatan kajian mengenai perancangan PdP di dalam kelas hafazan menunjukkan skor min sederhana tinggi $(\min =3.98)$. Dapatan ini menunjukkan guru tahfiz masih perlu meningkatkan tahap perancangan PdP khususnya dalam aspek pemilihan kaedah dan strategi PdP, perancangan bahan PdP dan perancangan masa PdP. Walau bagaimanapun guru tahfiz didapati membuat dan melaksanakan perancangan yang baik dari aspek penetapan matlamat dan perekodan hafazan. Hasil kajian ini menyamai dapatan Mohamad Marzuqi et.al (2018) yang menyatakan bahawa guru tahfiz sentiasa menentukan matlamat hafazan serta merekodkan dan menilai rekod hafazan pelajar secara berterusan. Rekod-rekod berkaitan hafazan ini amat mustahak kerana akan digunakan bagi tujuan pemantauan dan penilaian (Wan Ahmad Zakry, Firdaus Khairi, \& Azman, 2021)

Kelemahan dari aspek perancangan masa dan perancangan bahan pengajaran PdP jelas ditunjukkan dalam kajian ini. Perancangan dari aspek masa seperti masuk kelas lebih awal, menepati waktu semasa memulakan pengajaran tasmik menunjukkan tahap kurang memuaskan. Masa PdP tahfiz harus disusun dengan tepat dan lancar sebagaimana yang dinyatakan oleh (Wan Ahmad Zakry et.al, 2021) Ini adalah kerana masa untuk kelas halaqah perlu disesuaikan dengan nisbah pelajar. Di antara sebab guru tidak menepati masa kelas 
ialah sepertimana yang dijelaskan oleh Raedah (2013) bahawa tidak terdapat kawalan yang tertentu bagi memastikan guru masuk dan keluar kelas tepat pada waktu yang ditetapkan. Hal ini menyebabkan segelintir guru yang akan mengambil kesempatan untuk masuk lewat ke kelas dan melengahkan pengajaran dan pembelajaran.

Sementara itu dapatan turut menunjukkan guru kurang membuat perancangan bahan pengajaran yang secukupnya dan kurang menerapkan motivasi dalam set induksi supaya pelajar dapat bersedia sebelum kelas halaqah dimulakan. Hal yang demikian turut didedahkan oleh Misnan Jemali dan Ahmad Sadadi (2003) yang mendapati kaedah, strategi, teknik dan motivasi serta bahan pengajaran kurang diaplikasi oleh guru di dalam kelas. Justeru pelajar yang kurang diberikan motivasi di awal kelas kurang bersedia untuk aktiviti pembelajaran seterusnya.

Sekiranya perancangan dari bahan pengajaran dan set induksi yang dapat menarik perhatian pelajar boleh ditingkatkan sudah tentu amalan PdP tahfiz dapat diperkasakan sebagaimana ditegaskan oleh Norazman et.al. (2011) yang menyatakan bahawa guru-guru mampu menunjukkan amalan pengajaran yang baik melalui persediaan yang telah dilakukan. Perkara ini juga selari dengan saranan Rahil et.al. (2009) yang berpendapat bahawa amalan persediaan dan perancangan guru yang teliti amat penting dalam menghasilkan pengajaran yang efektif di dalam kelas. Perancangan strategik yang bijak akan menghasilkan pengajaran yang sistematik dan tersusun.

Secara keseluruhannya dapatan kajian mengenai penguasaan hafazan pelajar tahfiz menunjukkan skor min sederhana tinggi $(\min =3.83)$. Dapatan ini menunjukkan pelajar perlu meningkatkan lagi tahap penguasaan dalam pembelajaran tahfiz. Pelajar perlu menguasai bacaan al-Quran dan mengingati ayat al-Quran yang telah dihafaz khususnya aspek takrar yang konsisten, tahriri al-Quran, tasmi' rakan, fiqh al-ayat serta menguasai ayat-ayat yang Pelajar yang menguasai hafazan dengan baiak akan dapat membezakan ayat-ayat mutasyabihat lafzi. Seperti yang ditegaskan oleh Mahmud Lutfi Abd. Hadi \& Ahmad Shahir Masdan (2015). Dapatan ini disokong oleh pandangan Mariam Adawiah, dan Abdul Kabir (2018) yang menyatakan bahawa penguasaan memori pelajar tahfiz terhadap al-Quran sangat penting. Ia adalah merupakan suatu contoh nilai tugasan yang perlu disemai dalam jiwa pelajar tahfiz. Pelajar seharusnya mampu mengulang kembali ayat yang telah dihafaz oleh mereka agar mereka dapat menguasai dan mampu mengingat ayat tersebut.

Dapatan juga menunjukkan pelajar kurang mampu untuk menulis ayat yang telah dihafaz. Dapatan ini selari dengan dapatan kajian Farah Ilyani et.al. (2018) yang menyatakan bahawa aktiviti yang melibatkan penulisan al-Quran kurang dipraktikkan oleh pelajar-pelajar tahfiz. Perkara ini perlu kepada penambahbaikan semula kerana penulisan al-Quran merupakan salah satu aspek untuk memelihara hafazan al-Quran selain daripada aktiviti yang lain.

Aspek yang menunjukkan pelajar mula menguasai hafazan al-Quran ialah dapatan pelajar mampu memperbetulakan tajwid semasa menyemak hafazan rakan dan membaca ayat yang dihafaz semasa dalam solat. Hal ini bertepatan dengan Farah Ilyani et.al. (2018) yang menyatakan bahawa pelajar tahfiz mampu menjadi imam dengan membaca surah-surah yang telah dihafaz oleh mereka. Menguasai tajwid dan membaca hafazan di dalam solat merupakan sebahagian indikator pelajar menguasai hafazan mereka.

Kajian seterusnya menunjukkan terdapat hubungan yang signifikan pada tahap yang sangat kukuh di antara perancangan PdP tahfiz dengan penguasaan hafazan pelajar. Hal ini membawa maksud semakin baik perancangan guru tahfiz di dalam kelas hafazan maka semakin tinggi tahap penguasaan hafazan pelajar. Ini membuktikan bahawa aspek perancangan memainkan peranan penting bagi meningkatkan tahap penguasaan hafazan pelajar. Dapatan ini selari dengan dapatan Mohd Syaubari \& Ahmad Yunus (2018) 
yang menyatakan bahawa terdapat hubungan yang signifikan di antara komponen perancangan pembelajaran dengan pencapaian pelajar.

\subsection{KESIMPULAN}

Kajian ini telah telah menjelaskan tahap perancangan PdP tahfiz yang diamalkan oleh guru-guru tahfiz yang dikaji perlu ditingkatkan khususnya dari aspek perancangan strategi dan kaedah pengajaran, perancangan bahan pengajaran dan perancangan masa pengajaran. Dapatan kajian secara keseluruhan juga menunjukkan penguasaa hafazan yang mendapat skor min sederhana tinggi perlu ditingkatkan lagi khususnya menguasai takrar yang konsisten, tahriri al-Quran, tasmi' rakan, fiqh al-ayat dan penguasaan ayat-ayat mutasyabihat lafzi. Kajian telah membuktikan perancangan PdP tahfiz mempunyai kaitan langsung dengan penguasaan hafazan pelajar.

Implikasi kajian menunjukkan perancangan pengajaran dan pembelajaran tahfiz merupakan faktor penyumbang kepada peningkatan tahap penguasaan hafazan pelajar. Oleh yang demikian, perancangan pengajaran dan pembelajaran tahfiz harus disusun dengan lebih sistematik terutamnya pada aspek matlamat, masa, aktiviti PdP, bahan PdP dan perekodan agar dapat memberikan impak yang maksimum kepada penguasaan hafazan pelajar.

\section{Penghargaan}

Kertas ini adalah sebahagian daripada projek penyelidikan (GPU- 2019-0288-107-01) yang telah ditaja oleh RMIC Universiti Pendidikan Sultan Idris Tanjong Malim di bawah peruntukan Geran Penyelidikan Universiti UPSI. Penyelidik mengucapkan setinggi penghargaan dan terima kasih kepada pemberi dana, pihak institusi kajian yang terlibat serta rakan-rakan penyelidik yang menyokong penyelidikan ini.

\section{Rujukan}

Al-Quran dan terjemahan pimpinan al-Rahman, http://www.alquranmelayu.com/penghargaanacknowledgement / (Syeikh Abdullah Basmieh).

Abdul Hafiz Abdullah dan Hasimah Muda. (2003). Kaedah hafazan al-Quran yang sistematik dan praktikal dalam melahirkan para huffaz yang rasikh. Pusat Pengajian Islam dan Sosial. Universiti Teknologi Malaysia.

Abdul Hafiz Abdullah. Hussin Salamon, Azmi Shah Suratman, Sulaiman Shakib Mohd Noor, dan Kamarul Azami. Jasmi (2005). Sistem pembelajaran dan kaedah hafazan al-quran yang efektif: satu kajian di Kuala Lumpur dan Terengganu. Universiti Teknologi Malaysia. Laporan Penyelidikan UTM Skudai: Johor (2005).

Abu Najihat (2002). Panduan Bagi Hafiz-Hafizah dan Qari-Qariah. Penerbitan Darul Iman Sdn. Bhd. Selangor.

Ahmad Muaz Ahmad Othman \& Norazmi Anas. (2020). Evolusi Tadbir Urus Tahfiz Swasta di Malaysia. Jurnal Islam dan Masyarakat Kontemporari 21(2):127-133.

Ashraf Ismail. (2018). Amalan pengajaran pensyarah tahfiz di Maahad Tahfiz Al-Quran kelolaan JAKIM. Tesis Ijazah Doktor Falsafah. Universiti Kebangsaan Malaysia.

Azmil Hashim \& Kamarul Azmi Jasmi. (2015). Kaedah pengajaran dan pembelajaran tahfiz alQuran. Kuala Lumpur: Dewan Bahasa dan Pustaka.

Chua Yan Piaw. (2006). Asas statistik penyelidikan. Kuala Lumpur. McGraw Hill.

Farah Ilyani Zakaria, Mohd Aderi Che Noh dan Khadijah Abd Razak. (2018). Amalan Pembelajaran Pelajar Tahfiz di Institusi Tahfiz Swasta. Malaysian Journal of Education 43(3) 
Khairul Anuar Mohamad. (2016). Sistem kawalan kualiti huffaz. in book: Memperkasa generasi penghafaz al-Quran, Edition: 1, Publisher: Darul Quran JAKIM.

Mahmud Lutfi Abd. Hadi \& Ahmad Shahir Masdan. (2015) Penekanan terhadap ayat-ayat mutasyabihat al-alfaz ke arah pemantapan mutu hafazan al-Quran. Kertas kerja Seminar Antarabangsa Akidah, Dakwah Dan Syariah 2015 (IRSYAD2015), Kuala Lumpur, 12-13 Oktober 2015.

Mardhiah Yahaya. (2016) Pelaksanaan Modul Pengajaran Tahfiz (Modul Quranik) di MRSM Ulul Albab. Dlm. Mohd Yakub Zulkifli Mohd Yusoff \& Nordin Ahmad (pnyt.). Memperkasa Generasi Penghafaz al-Quran, hlm: 76-86.

Mariam Adawiah Dzulkifli \& Abdul Kabir Hussain Solihu. (2018) Methods of Qur'ānic Memorisation (Hifz): Implications for Learning Performance. Intellectual Discourse 26 (2): 931-947.

Misnan, Jemali. \& Ahmad Sadadi (2003). Hubungan antara teknik menghafaz al-Quran dengan pencapaian Kursus Tahfiz wa al-Qiraat pelajar semester empat dan lima di Maahad Tahfiz wal Qiraat di Perak. Seminar Teknik pengajaran Tahfiz al-Quran Peringkat Kebangsaan. Kolej Universiti Islam Malaysia.

Mohamad Marzuqi Abd Rahim \& Azmil Hashim (2016) Tinjauan terhadap faktor-faktor yang mempengaruhi penulisan ayat hafazan al-Quran dalam kalangan pelajar tahfiz. Jurnal Teknikal dan Sains Sosial. 5 (1): 93-102

Mohamad Marzuqi Abd Rahim et.al (2018). Ability in comprehending meaning of the Quranic verses among tahfiz students. International Journal of Academic Research in Business \& Social Sciences, 8(11), 1646-1656.

Mohamad Marzuqi Abdul Rahim, Ahmad Yussuf, Abd Hadi Borham, dan Muhammad Akramin Kamarul Zaman. (2016) Amalan Pengajaran Pensyarah Tahfiz al-Quran di Malaysia." Journal of Islamic Educational Research 1, No. 1: 11-20.

Mohd Jamalil Ismail, Sabri Mohamad, Tengku Intan Zarina Tengku Puji, dan Nor Hafizi Yusof (2017). Strategi Kecemerlangan Institusi Pendidikan Tahfiz Al-Quran Di Malaysia: Satu Tinjauan Literatur. Jurnal Islam dan Masyarakat Kontemporari 15 (1): 55-64

Muhaidi Mustaffa \& Siti Salwa Md Sawari. (2018). Managing standardize memorization strategy in tahfiz centres: A guideline for quality performance in Qur`anic memorization. International Journal of Research, 5(16), 1409-1417.

Muhammad Firdaus Zakaria. (2018) Kajian keberkesanan sistem pengurusan kualiti berteraskan Syariah MS1900 di Darul Quran JAKIM, Disertasi Sarjana. Universiti Malaya

Noraini Idris. (2013) Penyelidikan dalam pendidikan. McGraw-Hill Education.

Norashikin Abu Bakar, Ramli Basri, dan Foo Say Fooi. (2015). Hubungan kepimpinan guru dengan pencapaian akademik pelajar. International Journal of Education and Training, 1(2), 1-11.

Raedah Amin (2013) Pengurusan Pengajaran Dan Pembelajaran Sekolah Rendah Kebangsaan Di Zon Bandar Daerah Kota Tinggi. Laporan Projek Sarjana. UTM Skudai.

Rahil Mahyuddin, Habibah Elias \& Noreen Noordin. (2009). Emotional Intelligence, Achievement Motivation and Academic Achievement Among Students of the Public and Private Higher Institutions. International Journal of Diversity in Organisations, Communities \& Nations, 9(4).

Rohani Arbaa, Hazri Jamil \& Mohammad Zohir (2017). Model Bersepadu Penerapan Kemahiran Abad ke21 dalam pengajaran dan pembelajaran. Jurnal Pendidikan Malaysia, 42(1):1-11.

Siti Nurjanah Mustafa, Siti Aisyah Johan dan Jimaain Safar (2021). Tahap Pelaksanaan Aktiviti Hafazan dalam Kalangan Guru Tahfiz Sekolah Menengah [The Implementation Level of Memorisation Activities Among Secondary School Teachers]. BITARA International Journal of Civilizational Studies and Human Sciences (e-ISSN: 2600-9080), 4(1), 9-21.

Zulkifli, Mohd Yussof, et.al (2018). Trend masyarakat terhadap pendidikan tahfiz.ke arah pengiktirafan huffaz di Malaysia, 38-80. Terbitan Centre of Quranic Research dengan kerjasama Darul Quran Jakim. 


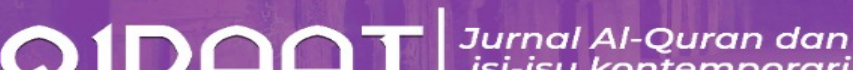

Zulkifly Md Alwayi, Rahimah Embong \& Huda Afiqah Hashim. (2020). Perancangan pengajaran guru dalam pembelajaran dan pemudahcaraan: satu kajian rintis. Asian Journal of Civilizational Studies (AJOCS),3(1), 11-18 